\title{
Camarneiro
}

\section{Tropical Purgatory: Brazil Through the Lenses of Stefan Zweig and Elizabeth Bishop}

Writers Stefan Zweig and Elizabeth Bishop both lived in Brazil, although in very different circumstances. Their stories served as basis for two films: Maria Schrader's Stefan Zweig: Farewell to Europe (Vor der Morgenröte, 2016), and Bruno Barreto's Reaching for the Moon (Flores raras, 2013). This article aims to describe the differences between these two films, and how they can be connected to Brazilian authors such as Gilberto Freyre and Sérgio Buarque de Holanda, whose works attempt to understand Brazil's social dynamics from the perspective of its violent colonial past. Furthermore, this article aims to question the connections between historical accuracy and political engagement, arguing that the general tone of a film narrative may sometimes be much more politically-oriented than the actual facts it portrays.

\section{Date submitted: 15/09/2020}

Date accepted: 09/04/2021

Keywords

FILM BIOPICS

STEFAN ZWEIG

ELIZABETH BISHOP

GERMAN CINEMA

MARIA SCHRADER

BRAZILIAN CINEMA

BRUNO BARRETO

BRAZILIAN SOCIETY

TERRESTRIAL PARADISE

Fabio Camarneiro 
This article analyses two biopic films that portray writers: Stefan Zweig: Farewell to Europe (Vor der Morgenröte, 2016), by Maria Schrader, and Reaching for the Moon (Flores raras, 2013), by Bruno Barreto. The first narrates four travels that Austrian novelist Stefan Zweig took through the Americas-in Argentina, USA, and Brazil. The second is focused on the troublesome romantic relationship between poet Elizabeth Bishop and Brazilian architect Lota de Macedo Soares. These two writers are depicted as not very assertive in the way they respond to external demands, and the difficulties in dealing with their respective problems would finally lead Zweig to commit suicide on February 22, 1942, and Bishop to become an alcoholic. In other words, the characters obey a much-repeated cliché that claims that artists suffer when the world around them suffers: Zweig during World War II, and Bishop during the first moments of a coup d'état in Brazil in the mid-1960s.

It is possible to identify Farewell to Europe and Reaching for the Moon as examples of a specific sub-genre with specific narrative traits, dedicated to the lives of famous writers. Both films could be analyzed in comparison with biopics of other writers who also committed suicide-Virginia Woolf in The Hours (Stephen Daldry, 2002) or Sylvia Plath in Sylvia (Christine Jeffs, 2003)_-or became alcoholic, as we see with Charles Bukowski's alter-ego Hank Chinaski in Factotum (Bent Hamer, 2005). However, our goal here is to analyze Zweig and Bishop through the notion of national identity. In both films, the main action takes place in Brazil, and the way the country is depicted reveals how, as Vidal puts it, "the biopic feeds fantasies of national identity to the international film scene (as seen, for example, in Coco Before Channel, 2009) but also blurs the contours of national cinemas through transnational encounters and appropriations (Marie
Antoinette, 2006, for instance)" (Vidal 2013, 2-3). As discussed below, the myth of the "tropical paradise" reveals itself in both films, forcing the characters to confront the distance between the myth and the actual country. It's also important to notice that an interface between national and transnational can be seen either in the Brazilian film about the life of the American writer, or in the European (Austrian-German-French) film about the travels of the Austrian writer in America.

Although these transnational aspects tend to be reinforced in international co-productions, they are rare in Brazilian biopics. Reaching for the Moon stands as an exception because of its concern for transnational aspects, and also for its focus on the life of a writer. In recent years, the country produced biopics focused mainly on musicians (We're So Young [Somos tão jovens, Antonio Carlos da Fontoura, 2013], Tim Maia [Mauro Lima, 2014], Elis [Hugo Prata, 2016]), TV personalities (Bingo: The King of the Mornings [Bingo: o rei das manhãs, Daniel Rezende, 2017], Chacrinha: o velho guerreiro [Andrucha Waddington, 2018], Hebe: a estrela do Brasil [Maurício Farias, 2019]), and even sports figures (Heleno [José Henrique Fonseca, 2012], Stronger Than the World [Aldo: mais forte que o mundo, Afonso Poyart, 2016], 10 segundos para vencer [José Alvarenga Jr., 2018]). Besides Bishop in Reaching for the Moon, only one other writer has been depicted in a recent Brazilian biopic: Paulo Coelho in The Pilgrim: Paulo Coelho's Best Story (Não pare na pista: a melhor história de Paulo Coelho, Daniel Augusto, 2014). But, since Coelho served as lyricist for rock and roll singer Raul Seixas, the film may also be considered among those about musicians, which is evident from its original title: instead of some reference to Coelho's literary work, "Não pare na pista" is actually the name of a song composed by Seixas, with lyrics by Coelho. 
As Vidal puts it, "the fundamental link to historical fact [...] seals the generic contract between producers and audiences of biographical film fictions, with the attendant pleasures of recognition" (Vidal 2013, 3). In fact, recognition seems even more important than accuracy, as audiences might be more familiar with certain myths and constructions of personae than with real events. This is the case with the two films here, in which historical facts are replaced by the myth of a "tropical paradise."

Since the time of its colonization by Europeans, the American continent has been recurrently interpreted by means of legends and myths based on its many natural beauty and mineral resources, among which the most recurrent is El Dorado, usually described as a lost city full of riches and precious stones. In the book Visão do Paraíso (Vision of Paradise), Sérgio Buarque de Holanda highlights the way in which mythical descriptions appear in several texts written by those who first described the continent, and draws the attention to a possible common origin of such descriptions: the medieval idea of the Terrestrial Paradise (Holanda [1959] 2000, 21).

In the 20th century, two writers-the Austrian Stefan Zweig and the North American Elizabeth Bishop-had to learn the differences between the myth and the actual reality of Brazil. Zweig and his wife, Lotte, managed to escape the Nazi persecution to Jews just before the Second World War, while Bishop arrived at the port of Santos in her wish to spend a few months getting to know the country. After five months living in Petrópolis and unable to forget the devastating events in Europe, the Zweigs committed suicide. On the other hand, Bishop stayed in Brazil for more than fifteen years.

The encounter of these writers with the myths created from the idea of a tropical paradise is at the core of both films. It is also notable the presence of a heritage of sociological studies by authors such as Buarque de Holanda and Gilberto Freyre, in their attempts to understand Brazil's national identity from the perspective of its violent colonial past. In what follows, this article also aims to question the connection between historical accuracy and political engagement, arguing that the general tone of a film narrative is sometimes much more political than the actual facts it portrays.

\section{Stefan Zweig between Europe and the Americas}

In February 1934, a few months after Zweig's books were banned in Nazi Germany, Vienna witnessed four days of civil war that ended with the victory by the Vaterländische Front, a political party with a fascist inclination. Although Zweig was there during this event of social turmoil, he described in his autobiography that almost nothing in the city center reflected the battles that took place in the outskirts (Zweig [1942] 2014, 330). On the other hand, some chapters of this book are a testimony of how the situation in Austria became increasingly tense, particularly for Jews. At that time, many decided to leave the country, including Sigmund Freud and Stefan Zweig himself. Both decided to move to London, where Freud died in September, 1939. A few weeks after his death, Poland was invaded by Germany and the United Kingdom declared war on Germany.

Therefore, Zweig ran the risk of being arrested, or worse, deported. As his life in Europe became increasingly unbearable, fleeing was one of the few possible options. Zweig and Lotte soon crossed the ocean to the United States. Months later, they decided to live in Brazil, more specifically in Petrópolis, a small town in the hilly countryside of Rio de Janeiro.

Maria Schrader's film portrays none of these episodes. Instead, its narrative 
has as its focus four different trips that Zweig made through the Americas, each one of them announced by an intertitle: the first episode takes place in 1936, three years before the Second World War, in a PEN Congress held in Buenos Aires, Argentina. The others take place in 1941 in the Brazilian state of Bahia; in 1940 in New York; and finally in 1942, in Petrópolis.

However, there is a short prologue that precedes these episodes. It shows a large and rich table being prepared by people wearing formal uniforms, white suits, and bow ties. The scene is accompanied by a samba played in the background (a song called "Emilia," by Haroldo Lobo and Wilson Batista, here with new lyrics by Ru Paes de Vasconcellos). After the applause, the doors of the room open in a rehearsed, almost choreographic manner. Some of those who have been watching the musical presentation gradually move into the room as the film's audience are ushered into the movie's narrative.

The event is held as an homage to writer Stefan Zweig in his first visit to Rio de Janeiro, in 1936. As in any official ceremony, details must be impeccable and display some level of sophistication. At the center of the table, a large flower arrangement exhibits its vibrant colors. In a close-up frame, this same bouquet is the very first image of the movie and serves as a reference for both the framing and the dynamics of the entire scene. In addition to the use of such flowers and their colors being a cliché associated with the tropics, its presence may also be interpreted as an omen of the tragic destiny of the main characters. It is important to point out that, in Brazil, similar bouquets are also placed inside coffins, as shown in Di Glauber (1977), Glauber Rocha's short film about the funeral of the painter Emiliano Di Cavalcanti. Furthermore, in Farewell to Europe, the camera is set at a high angle so as to suggest the shape of a coffin (Fig. 1).
Such details define the tone of the film and place it between elegy and irony, as if the Zweigs had been dead from the very beginning, but still had to attend the different ceremonies and official formalities shown throughout the film. Therefore, the film seems to depict a long funeral marked by melancholy and farewells, which is made evident in its title translated into English, Farewell to Europe. Even though the Zweigs managed to flee from death in Europe, they seemed to head into it inexorably. All of these aspects are present in the performances by Josef Hader (Zweig) and Aenne Schwartz (Lotte), either by their constantly exhausted bodies or by their apparent disbelief in their future.

The discomfort of the characters is also the core of another sequence in the movie, when the couple is received by the mayor of a small town in Bahia. This second event is in all aspects different from the first. Although it would be expected to be impeccable, it ends up as something of a mess, improvised at the last minute by a team of amateurs. The mayor is a typically comical character: quite short and chubby, with hasty moves and gestures, he exhibits restlessness in his attempt to make things work, and embarrassment when nothing happens as it should, all of which seem to be based on popular comedy. In homage to the writer (whose last name is insistently mispronounced by the mayor), "The Blue Danube" waltz, by Johann Strauss II, is played out of tune and slightly syncopated, which makes it sound like samba. The Austrian piece, played to pay homage to the writer, is accidentally transformed into the most recognized Brazilian popular rhythm. This episode reveals how the "fantasies of national identity" can create cultural shocks. When trying to play European classical music, the musicians actually play a misplaced Brazilian rhythm. This failed attempt to act like a foreigner 


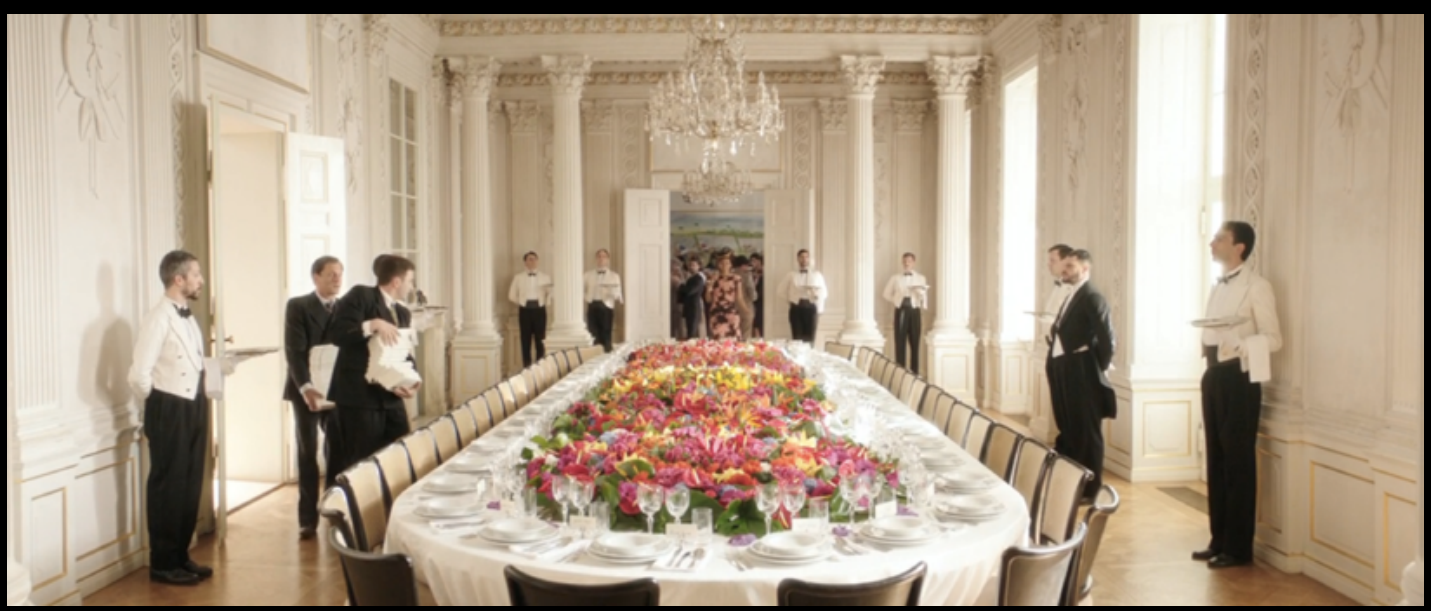

Fig. 1: The flower arrangement in Farewell to Europe (Maria Schrader, 2016).

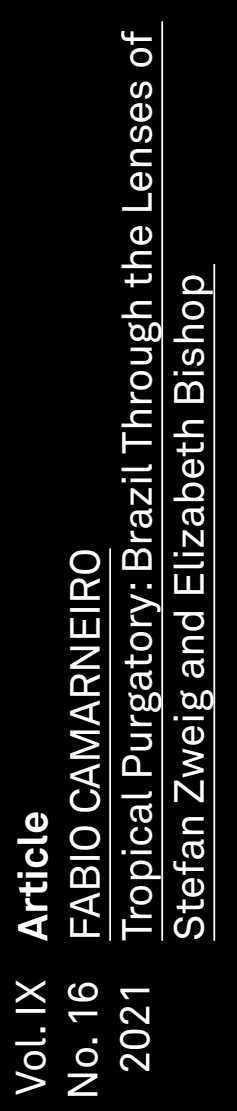


reveals what Paulo Emilio Sales Gomes referred to as the Brazilian cinema's "creative incompetence for copying" (Gomes [1973] 2016, 190). ' The more the Brazilians fail in such disguise, the clearer such "incompetence for copying" can be noticed.

In the same sequence, some other cultural aspects of Brazil are made visible, particularly by the treatment dedicated to those seen as important or relevant persons. The emotion demonstrated by the women who welcome Zweig highlights the writer's popularity in the 1930s, when his books were published in several languages around the globe. On the other hand, it also demonstrates a type of (false) intimacy that is very common to social relationships in Brazil, a modus operandi that usually ignores any official protocols. One example is the moment at which they offer "homemade desserts" to the guests as if they were members of their own families. Behaviors like this caused Brazilians to be seen and understood by their visitors as "open, relaxed, laidback" or, at least, as "extroverts." However, the issue may be completely different. According to Sérgio Buarque de Holanda in his influential book Raízes do Brasil (Roots of Brazil), this aspect of the Brazilian personality demonstrates the confusion involving the public and private spheres that dates back to its long past of colonization by the Portuguese. For the author, Brazilians didn't know "any other form of sociability other than that ruled by an ethic based on emotions" (Holanda [1936] 1995, 148). This sequence of the film allows us to perceive this mechanism in its spatial structure. While in the coffintable sequence the orchestra was off screen, in this sequence nothing remains hidden. There are no private or backstage spaces. Everything is visible all the time: the mayor adjusting his tie as his wife tries to calm him down, the musicians that arrive on a truck and hurry to prepare everything. The close-ups of the Zweigs reveal that they can perceive this "intimacy" as false. The more uncomfortable they are, the clearer the film demonstrates a description of this Brazilian practice.

Throughout the entire film, it is possible to notice that the open spaces are common in the sequences set in Brazil, filmed mostly outdoors, but not in the sequences which depict the trips to Argentina and the United States, which are mostly indoors. This trait echoes the idea of the country as a tropical paradise, a "stereotyped place [...] that does not know pain, sadness, or disease," blessed with "springtime weather, not very cold nor very hot," where "humanity could realize the dream of the Age of Gold" (Holanda [1959] 2000, 387). The only exceptions are precisely the first and the last sequences of Farewell to Europe: the prologue (which, according to our analysis, announces the death of the leading characters), and the denouement (when they are found dead in their bedroom in Petrópolis). These two sequences take place indoors. Moreover, they establish a distinct relationship between visibility and concealment, between what is in the scene and what can effectively be seen in it: in the first case by not showing the musicians playing the samba, in the second by not revealing the dead bodies until the last moment.

The incapacity to see what should be evident is also one of the features that are related to the book Zweig wrote about the country. In Brasilien: Ein Land der Zukunft (Brazil: A Land of the Future), he repeats the myth of the tropical paradise and describes the country as an idyllic place, a "completely different type of civilization." Among other exaggerated conclusions, he affirms that "nowhere else have slaves been treated in a more relatively humanitarian way" (Zweig 
[1941] 2013, 206). Obviously, being someone that had escaped from the Nazi persecution, it is not surprising that he praised the peaceful way in which Brazilians led their lives, since, from his perspective, they were free from any and all racial prejudice. Zweig either could not perceive the structural racism of Brazil, or had a very condescending and optimistic idea of it all. Today, no serious intellectual would ever agree with such ideas. However, the idea of a less violent form of slavery was not unusual in the 1930s. Back then, Brazilian sociology was deeply marked by the works of Gilberto Freyre and his influential book Casa-Grande \& Senzala (The Masters and the Slaves), published in 1933.

In his book, Freyre described the concept of "racial democracy" (currently seen as a fallacious idea) that, back then, inspired many other works about Brazil, including Zweig's book. Although Freyre himself suspected that Zweig had not even read Casa-Grande \& Senzala (Dines 2004, 403), Zweig publicly praised Freyre's work (Dines 2004, 417), which reveals that Zweig's knowledge of Freyre's ideas may have come from secondary sources. Even though Freyre may now be accused of perpetuating racist ideas in Brazilian society, the concept of racial democracy played a central role in the revaluation of the importance of the Black and native Indigenous cultures for the country's identity. Before Freyre's work, most Brazilian intellectuals tended to imagine ways to "improve" Brazilian society, that is, to make it more "civilized." In their concept, "more civilized" also meant more European and "whiter" (Miskolci 2012, 234). Hence, after centuries of slavery, there has been an attempt to diminish the importance of the existence of Black and native Indigenous people in the constitution of the country. This was an underlying motive for the Brazilian government to incentive the immigration of Europeans, mostly poor people, after the legal abolition of slavery in the country, signed in 1888. During the First World War, and after it, Brazil received many people from the countries defeated in that conflict. Therefore, large numbers of Italians and Germans, mostly, migrated to the South and Southeast regions of the country. In this context, Freyre's work is important for having served as a turning point that allowed for the recognition of the African and Amerindian heritages involved in the construction of a national identity. Despite the importance of such work, Freyre did not manage to abandon a "romantic" vision of slavery, the same vision Zweig reproduces in his own book. As the narrative of Farewell to Europe is marked by the writer's perspective, we can also see that approach in the film, for its incapacity to perceive any traits of violence in Brazilian social relationships.

The few Afro-Brazilians depicted in the film are always gentle and willing to assist with whatever comes their way. The most obvious example may be the employee of the sugarcane farm. With a smile on his face, he insists on establishing a conversation with Lotte and, in another attempt to demonstrate intimacy, asks her questions about children, among other topics. Expecting perfect historical accuracy from a film is almost always a naïve exaggeration. Nevertheless, we are led to ask ourselves if an employee of a farm in Bahia in the 1930s could have been like that, if his clothes and boots could have been so tidy as to appear almost new, and if his looks could ever be so healthy and merry (Fig. 2).

In Farewell to Europe, the images are far from realistic, and appear to relate to Zweig's naïve illusions of Brazil and some of the ideas from Casa-Grande \& Senzala. An idealized perspective, in which the relations between white landlords and Black slaves are 


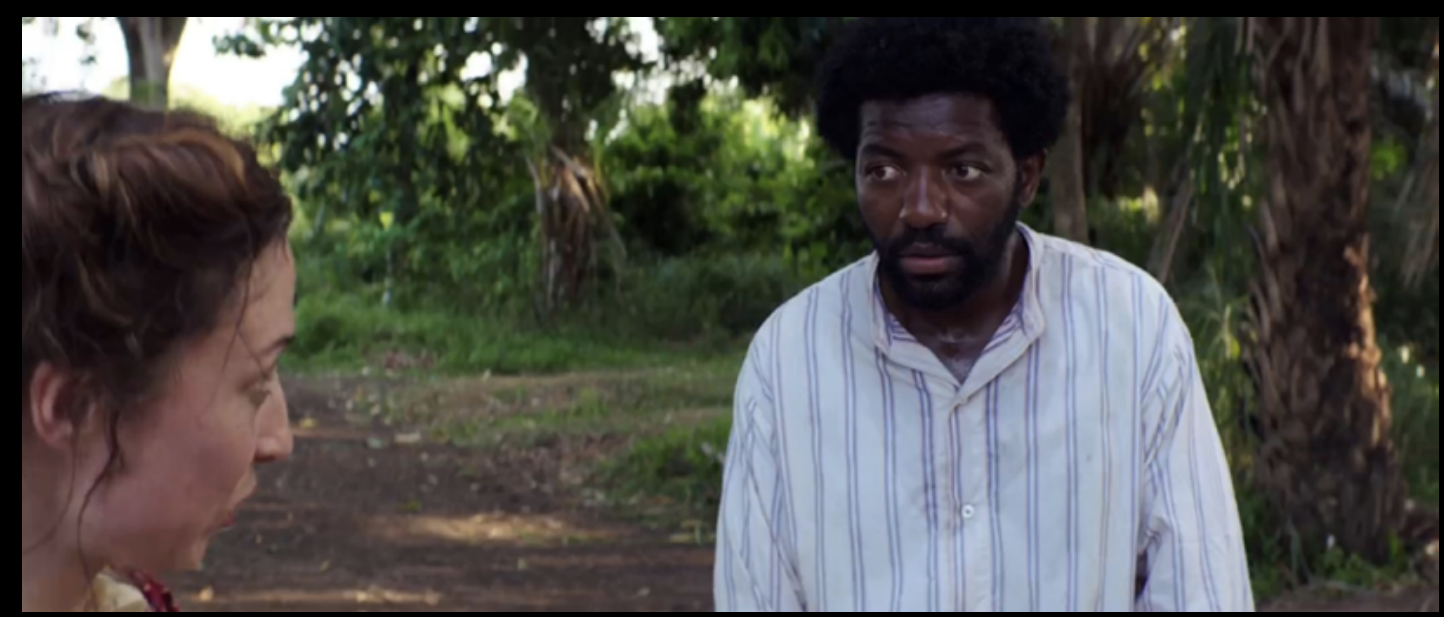

Fig. 2: The employee of the farm in Farewell to Europe (Maria Schrader, 2016).

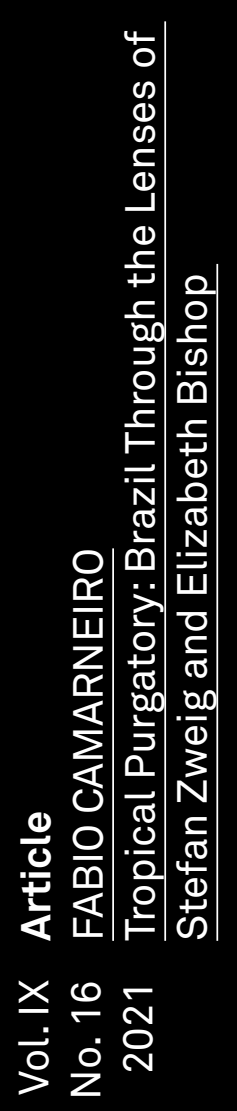


depicted with nostalgic tones, also marks Freyre's book, maybe due to the author's memory of episodes of his own childhood in a large farm owned by his family in the state of Pernambuco. Freyre was born eight years after the decree that abolished the slavery in Brazil, and very few things had changed since then in those large farms.

Following Freyre's impressions, the slightly fanciful aspects of the film further reinforce the distorted perceptions its main characters have about the country. It is important to notice that Farewell to Europe was not filmed in Brazil, but in Portugal and in São Tomé and Príncipe. As a film made outside of Brazil, it reflects many stereotypes related to the idea of "fantasies of national identity," including the fact that all outdoor sequences have a bright sunny light; or that everyone does its best to be nice and friendly to the foreign couple; or that life in Brazil seems to be free from racial or social issues. None of that is close to the reality of a very mixed and complex country, which is far from the tropical paradise cliché, but also from a simple series of binary oppositions: rich and poor, European culture and amateur musicians, war outside and peace inside. Two countries together at the same time: the positive and the negative; an idealized country and its inverted image. A symmetry disturbed by the Zweigs' death.

In fact, the structure of Farewell to Europe is built around the token of Zweig's suicide. Instead of demonstrating that the idealized Brazil imagined by the writer does not actually exist, the movie suggests that losing his homeland made it impossible for Zweig to remain alive-even though he was far from the war, living in a supposed tropical paradise. In his dialogue with the mayor, the writer says that "Europe has a rich past, but Brazil is the country of the future." Soon after, in a faux pas, the mayor ends his speech stating that "a man without a nation has no future." The conclusion is that the country has a future, but the man without a nation does not. Once again, this demonstrates the announced death of the character, and at the same time, confirms the survival of Brazil as the myth of a tropical paradise.

\section{Paradise is (not) here}

By the end of 2019, the cultural scene in Brazil was seized by a controversy involving the name of Elizabeth Bishop. After eighteen years as one of the most important events dedicated to literature in Brazil, the International Book Fair of Paraty (in Portuguese, "Festa Literária Internacional de Paraty," or FLIP) announced that its 2020 edition would include a foreign writer as the festival honoree. Soon after, several negative reactions questioned the choice of Bishop in lieu of a Brazilian author. Such criticism was mostly due to the unawareness of the fact that Bishop had lived in Brazil for almost fifteen years, and that her translations played a crucial role in the worldwide dissemination of the works of writers such as Carlos Drummond de Andrade and João Cabral de Melo Neto. FLIP's selection of the name to be honored took into account Bishop's important work in disseminating Brazilian poetry, as she made it more accessible to foreign readers.

Also, some of that criticism was more deeply related to Bishop's political opinions. It particularly emphasized her reaction to the civil-military coup d'état in 1964, which led to 21 years of dictatorship in Brazil. In her letters, Bishop suggested that she agreed with it. Less than two weeks after the coup, she wrote to her close friend, the poet Robert Lowell: "The military junta probably looks much worse from outside than it does from here. [...] The suspension of rights, dismissing lots of 
Congress, etc. - had to be done, sinister as it may sound" (Bishop and Lowell 2010, 530). It is important to point out that her partner Lota de Macedo Soares (and, therefore, Bishop herself) was a close friend of Carlos Lacerda, a rightwing politician, a detractor of president João Goulart, and an enthusiast of the coup. Regina Przybycien, in her analysis of the poet's letters, affirms that Bishop had "a Manichean vision of Brazil, where communists and populists are the black hat and Lacerda is the white hat in Brazilian politics" (Przybycien 2015, 39).

When FLIP announced its selection, a significant number of intellectualspoet and essayist Antônio Carlos Secchin, poet and diplomat Felipe Fortuna, Portuguese journalist and writer Alexandra Lucas Coelho, among others-deemed it impossible to pay homage to someone that had been so tolerant to the coup d'état (Agência Lusa 2019). Particularly when the very president of Brazil-Jair Bolsonaro, a far-right politician-did not miss any opportunity to praise the "movement" that, in his words, would have saved Brazil from the dangers of communism. In September 2020, during a radio and television broadcast celebrating Brazil's Independence Day, Bolsonaro described the 1964 coup d'état as follows: "When the shadow of communism menaced us, millions of Brazilians, identified with the national wish to preserve our democratic institutions, went to the streets against a country marked by ideological radicalization, strikes, and corruption" (Machado and Carvalho 2020). In such a context, many viewed the selection of Bishop as inappropriate, at least, or even unacceptable.

Amid the debates, no one could have imagined that Covid-19 would impose the postponement of the 2020 edition of FLIP, first planned to be held in July. In August, the festival organized a series of round table events to discuss several themes of Bishop's works. By the end of the month, FLIP's lead curator Fernanda Diamant resigned, explaining once again the reasons to have chosen Bishop, but without responding to the debate itself. She declared that, due to the pandemic, "the celebration previously designed seemed to belong to another time, and has lost its sense," and that the festival "needed a black woman as curator" (Folha de São Paulo 2020). A few days after Diamant's resignation, the homage to the American poet was officially cancelled. FLIP 2020 was finally presented online for 3 days in early December. This fact put an end to the controversy, but also to the short period in which the relationship between Bishop and Brazil was discussed as it had never been before.

Also, this indicates that, rather than Zweig's extreme optimism, the American poet had contradictory relations with the country where she lived between 1951 and 1965. When Bishop arrived in Brazil, she could not have imagined that her stay would be so long, but a series of incidents-such as her hospitalization in December 1951 due to an allergic reaction triggered by the ingestion of a slice of cashew - saw her extend her time in the country. In a letter written a few days before falling ill, Bishop said she was planning to leave Rio de Janeiro by the end of the following January (Bishop 2014, 226). The illness changed her plans. Above all, it seems evident that the main motivation for Bishop's long stay in Brazil was her relationship with Lota de Macedo Soares, described in detail in the book Flores raras e banalíssimas: a história de Lota de Macedo Soares e Elizabeth Bishop (Rare and Commonplace Flowers: The Story of Elizabeth Bishop and Lota de Macedo Soares), by Carmen L. Oliveira (1995), which also served as a baseline reference for Bruno Barreto's film.

Macedo Soares was a Brazilian architect who was responsible for the construction of one of the most 
important green areas in Rio de Janeiro: the Flamengo Park ("Aterro do Flamengo" in Portuguese). In Reaching for the Moon, Macedo Soares (Glória Pires), or "Dona Lota," as she was usually referred to, is depicted as a strong, determined, resourceful woman capable of talking with politicians or blue-collar workers on equal ground. In fact, she was a wealthy, sophisticated woman, who demonstrated the fusion of a strong self-assurance with a solid European education.

On the other hand, Bishop (Miranda Otto) is described a little differently. Even though she also had a solid and sophisticated education, in the film she seems to lack resolve. Actually, as depicted in the film, Bishop was always struggling with her emotional fragility and her addiction to alcohol. In a brief sequence, she is seen late at night entering a typical Brazilian bar-known as a botequim - a place quite different from the upper-class spaces Bishop and Macedo Soares used to frequent. At the botequim, she orders three shots of "your best cachaça" (a distilled spirit). Here, the racial issue is also evident. Everyone is white in the upper-class spaces seen in the film, except for the black employees. On the other hand, in the botequim, except for the elegant American woman asking for cachaça, everyone is black.

Like Zweig, she also wrote a book about her adoptive country, although less ambitious than Brasilien: Ein Land der Zukunft. Brazil was ordered by Time-Life Magazine as a travel guide for its Life World Library collection, although Bishop never thought of the book that way. As soon as it was published, the author disdained it, and she kept this stance throughout her whole life. The reason for such was due to the several changes made to her texts, both in their contents and style, so as to fit in the Time-Life standards. Bishop insistently sent letters to her friends, in which she criticized the final results (Przybycien 2015, 48). However, that very ordered job also gave her the opportunity to travel through a considerable part of the Brazilian territory and provided her with the opportunity to take a closer look into the country.

Travelling was one of Bishop's passions, and the rest of her time was split between two of Dona Lota's estates: an apartment by Leme beach, in Rio de Janeiro, and the countryside house in Petrópolis, the very same town where Zweig lived. This house, called "Samambaia" (named after a local type of fern), was designed by Brazilian architect Sérgio Bernardes. However, Reaching for the Moon does not show the actual house. Instead, it sets the action in another house in Petrópolis, designed by Oscar Niemeyer, with a sculpture in the garden by Alfredo Ceschiatti, a modernist artist (Fig. 3, top).

The choice to connect Niemeyer, Ceschiatti and Macedo Soares suggests that the film intended to create a type of cliché of the Brazilian modernism, an image that can be easily identified by its target audience. In spite of the fact that Reaching for the Moon was produced and directed by a Brazilian filmmaker, one of its characteristics is the way in which cultural aspects are made simpler, easier for foreigners to understand; an approach not very different to that used by the editors of Time-Life when it comes to Bishop's book. For instance, the film shows the colonial city of Ouro Preto (Fig. 3, bottom), in the state of Minas Gerais, but does not explore the poet's fascination with the architecture that led her to buy a house in its historic center in 1965 (Przybycien 2015, 25). Instead, the film uses that scenery in a sequence in which Dona Lota and Bishop have an argument. So, the landscape of Ouro Preto is not used as an expression of the characters' personalities, but it is just a background for their story. 

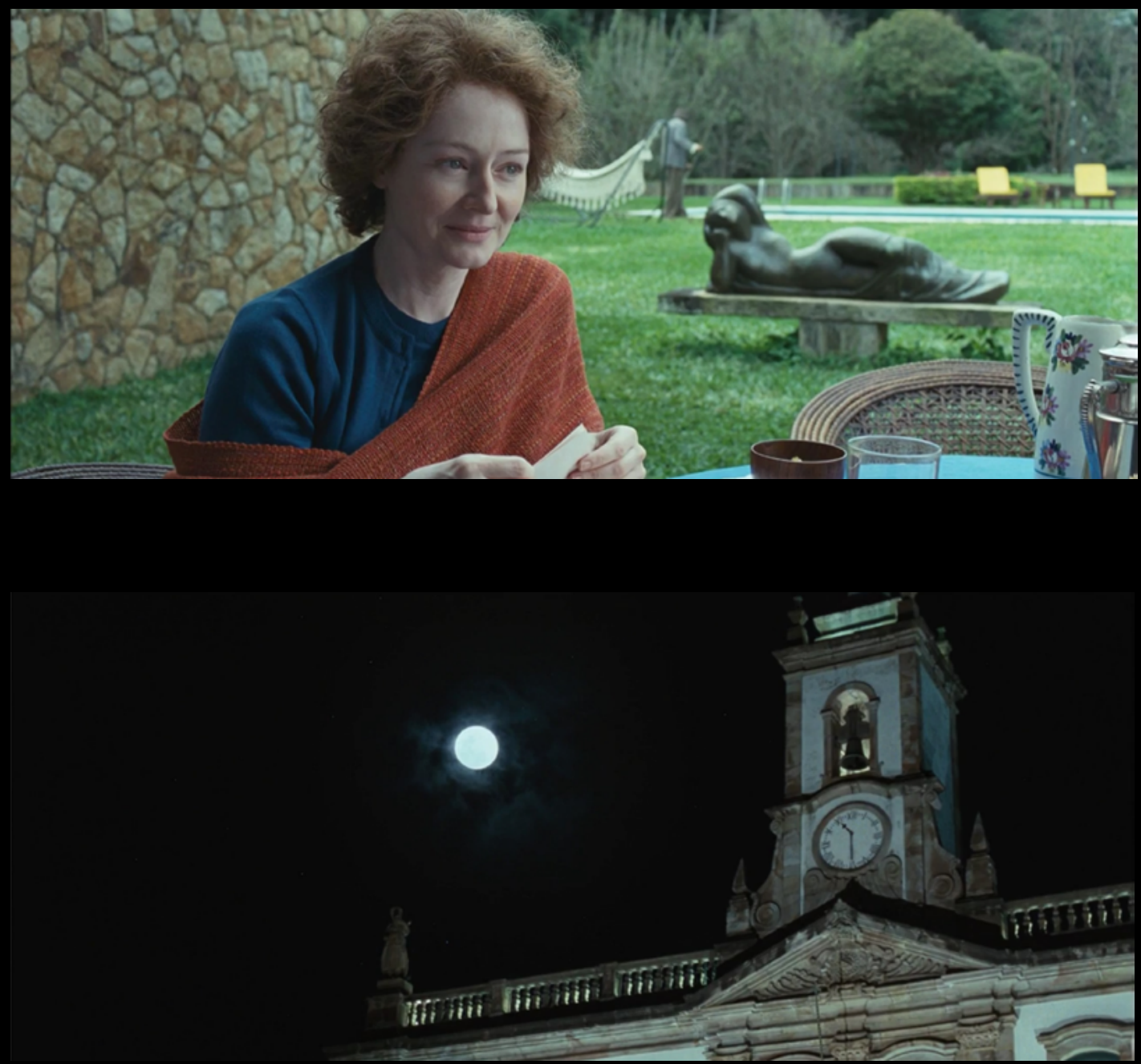

Fig. 3.

Top: The modernist sculpture in Reaching for the Moon

(Bruno Barreto, 2013).

Bottom: The architecture of Ouro Preto in Reaching for the

Moon (Bruno Barreto, 2003). 
Even though she was surrounded by the artistic elite of Brazil and wellregarded by all, Bishop soon became aware of the severe social inequality and the general indifference to political matters in the country. As an example of the latter, the film shows indifferent people playing soccer on the beach on a sunny day while, at the same time, the news media report the fall of president João Goulart. It is important to point out that, in contrast to the real Bishop, the character in the movie does not condone the military coup d'état at all, which she understands as a threat to democracy. Such a change may be questionable but, at least in Brazil, it is reasonable from a commercial, calculated perspective. In Brazil, if both women were presented as supporting the military coup d'état, the left-wing audiences to which the film is presumably addressed might soon stop empathizing with them. Therefore, Bishop had to be made the American champion of democracy, a familiar cliché for audiences used to watching American films. Even being a Brazilian film, Reaching for the Moon chooses legend instead of historical truth: although the American government's support of the military and anti-democratic coup d'état in Brazil is now very clear, the film depicts Bishop as the champion of America's highest democratic standards. This is highlighted when she and Macedo Soares have an argument because Bishop publicly demonstrates her concerns about the political situation in Brazil, in a position very distant from the one that the historical Bishop adopted in her letters.

Therefore, the fictional character of Elizabeth Bishop becomes even more concerned with the social issues of Brazil than the real Bishop did. She understood Brazil very well, at least much better than Zweig did. But, in an interview, she also repeated Gilberto Freyre's ideas about racial democracy, and stated that the USA had a lot to learn from Brazil when it came to racial issues (Monteiro 2013, 38). In a scene from the film, in a formal event, the poet makes a clear speech against the military forces and is immediately rebuked by Macedo Soares as she recalls her relationship with Lacerda, the governor of the State of Guanabara. Lacerda was an enthusiastic supporter of the civil-military coup d'état and was later a victim of the unpredictable twists in the government. His political rights were revoked by the very regime that took power with his help. During Lacerda's government, Macedo Soares started the construction of Flamengo Park, which constitutes one of the main dramatic plots involving her character in the film, the other being her relationship with Bishop.

In spite of its somewhat romanticized narrative, and inaccuracies in its historical references, the film is somewhat more complex in its approach to Brazil than Farewell to Europe. Its characters are an artist, architect, and lesbian woman, related to right-wing politicians, and a North American poet who, in contrast to Zweig, doesn't see a country with a promising future, but with a violent past and a present marked by numerous inequalities: a country in which Dona Lota can treat blue-collar workers "head-to-head," while they cannot treat her the same way; a country in which, on the one hand, the elite can afford to send their children to study in Europe, and on the other, the children and grandchildren of enslaved Black people live in very precarious conditions. This distance between social classes becomes evident when Dona Lota decides to "adopt" a child in an attempt to satisfy the wish of her former partner, Mary Morse (Tracy Middenmorse), a friend of Elizabeth who had arrived in Brazil before and was the one who introduced her to Lota. In fact, Dona Lota simply buys a child from a poor family. When 
seen from Mary's perspective, this scene emphasizes an aggressiveness that is not even masked in Brazil. The reverse shots of Mary's face reveal her mixed feelings: even though she wants the opportunity to raise a child, it does not seem right to her that a child can be bought or sold as a good. But both Macedo Soares and the maid argue that the child would be sold anyway, to them or to someone else. Their conclusion is that, by buying the child, they are doing the poor mother a favor. Here, the idea of a racial democracy is exposed as a fallacy, since some lives can still be negotiated as long as there are people willing to pay for them; it is as though very little had changed since the abolition of slavery.

\section{The role of the intellectual}

The films analyzed here present two writers that experienced the social problems of Brazil and the heritage of the years of slavery. But what could they do to fight them? A similar question about the situation in Europe is made during the PEN congress in one sequence of Farewell to Europe, when private conversations and public interviews have only one theme: how to stand against Hitler. Zweig chooses not to respond promptly. He seems to insist on dodging the subject or using a conciliatory approach. He claims to feel uncomfortable criticizing Germany, as his German culture and language would be, as he says, "his true homeland." In an interview, some journalists insist on obtaining a more striking declaration from the writer, with no success. He prefers to separate art from politics. Later, during the opening of the congress (as in many other moments in the movie), Zweig becomes uncomfortable again, with the harsh opening speech that denounces persecution by Nazi Germany against Jews and other opposers of the regime. Then, the names of several authors that had to flee from Germany to escape persecution are read out loud. These names include Stefan Zweig, but perhaps the most notable name in this list is that of Walter Benjamin.

The German philosopher also committed suicide in September, 1940, while trying to flee from occupied France. In his writings from the 1930s, in contrast to those of his Austrian peer, Benjamin defended the constant politicization of the arts to combat Fascism and what he referred to as the "rendering aesthetic" (Benjamin 1969, 242) of politics. Art cannot exist detached from its social, political, or economic contexts. Therefore, artists should always take their situation in the world into consideration, and be aware that, for art to exist, it depends on the same conditions of production as those of any other contemporary commodity. Hence, Benjamin believes that no artist can imagine him or herself apart from the dynamics of real life, current political issues, or public debates. In short, no artist could take actions similar to those of Stefan Zweig in Farewell to Europe.

In this sense, for the author of Brasilien: Ein Land der Zukunft, Brazil was a myth, the tropical paradise inside another myth of art's autonomy in face of the real world. Based on these ideas, Zweig believed that he could move to Brazil and simply start a new life dedicated to writing. He imagined that it would be possible to find refuge in literature and escape the violence in Europe, as well as to escape his own time in history. However, his mistake was to ignore that such escape is not possible-except in death.

Zweig and Bishop looked at Brazil through distorted lenses. In the two films, both of them appear behind glass windows (Fig. 4). In both scenes, the glass reflects their faces and reveals the outside at the same time. The windows here may recall the myths that prevent writers from understanding the world around them, or may simply refer 

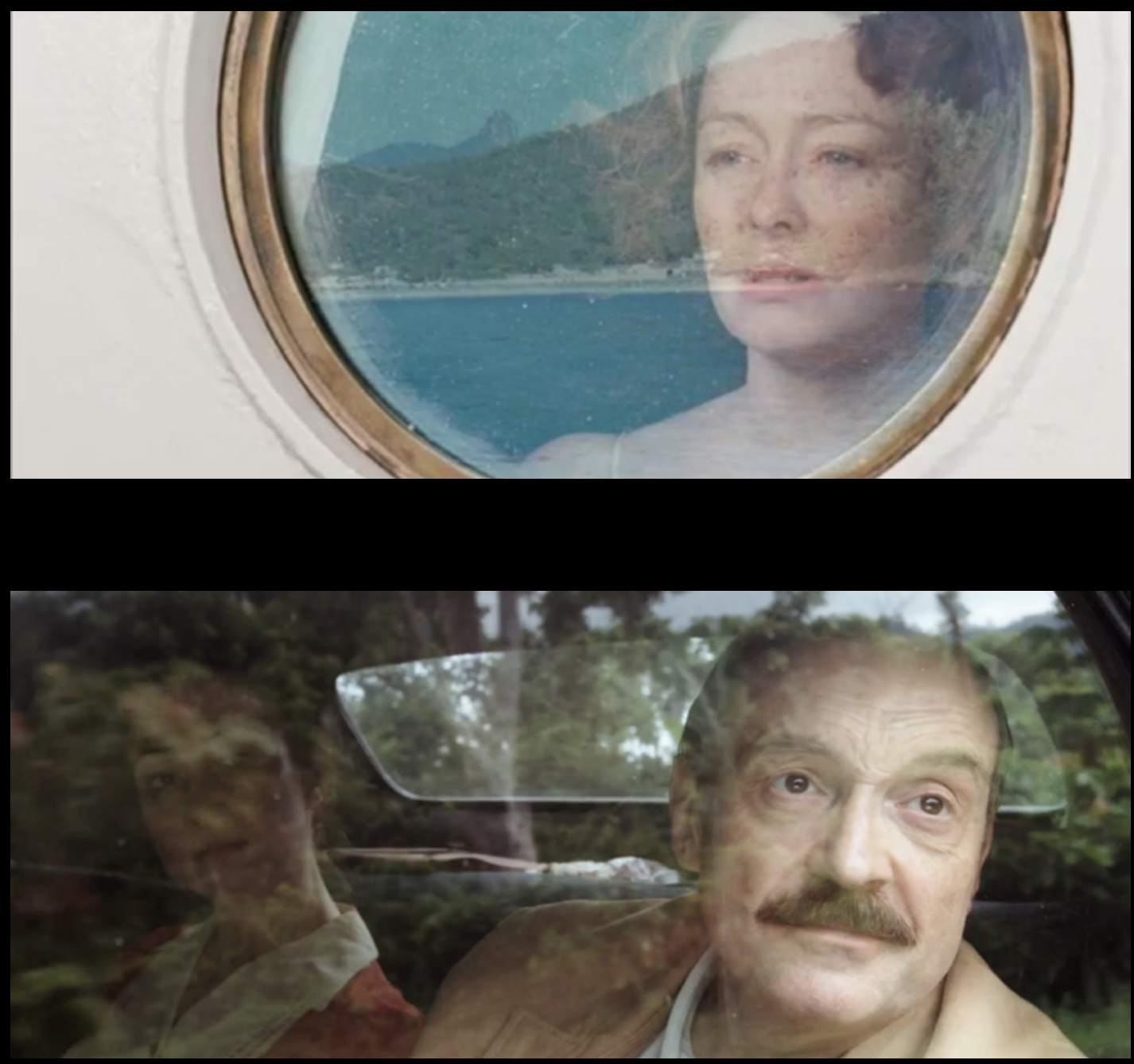

Fig. 4.

Top: Elizabeth Bishop (Miranda Otto) looks through the

glass in Reaching for the Moon (Bruno Barreto, 2013).

Bottom: Stefan Zweig (Josef Hader) looks through the glass

in Farewell to Europe (Maria Schrader, 2016). 
to literature itself and the way writers try to put their inner lives in contact with their historical times. Benjamin's goal was not to cause artists to break such windows, but to bring their attention to their unavoidable existence.

Brazil has always been very far from the racial democracy imagined by Gilberto Freyre (and echoed in the works by Zweig and Bishop). Under the myth of a tropical paradise lies an authoritarian and extremely violent country. Instead of a "more human" treatment, it is known today that, in the 16th century, the average lifespan of a enslaved person in Brazil was approximately 10 years shorter than that of an enslaved person in the United States (Schwarcz and Starling 2015, 152). The years of military dictatorship witnessed the persecution and assassination of those against the regime, which caused many of those who managed to survive to leave the country. Now, the government of Jair $\mathrm{M}$. Bolsonaro seems to, once again, reveal and highlight the violent treatment given to native Indigenous populations, LGBTQI+ people, among others. Moreover, the absence of an effective policy to deal with environmental issues has led to striking records of deforestation in the Amazon and in the flood lands of Pantanal. One of the core ideas of the myth of a tropical paradise, its lush nature, now runs the risk of disappearance.

In Reaching for the Moon, the social violence is depicted in a way that is not mentioned in Farewell to Europe. However, Bruno Barreto's film needs to build a false character when it comes to Bishop's historical role. In this sense, the artificial aspect of Maria Schrader's film is, perhaps in a paradoxical manner, closer to reality and more coherent with the way Zweig himself understood Brazil. More coherent with its characters, Schrader's film describes a Brazil that does not exist in reality, but only in the mind and writings of Stefan Zweig.

Ultimately, while Reaching for the Moon distorts historical facts in an attempt to reach a "real" conclusion, Farewell to Europe is absolutely faithful to the fantasies of national identity of its character and seems closer to another type of truth believed uniquely by Zweig. In order to escape both misconceptions, it would be necessary to return to Walter Benjamin, for whom history is a storm that pushes us into the future while our minds are focused back on the past (Benjamin, 1969, 257-8). Hence, unaware of where we are heading, we can only collect the debris that history leaves along the way. Some of this debris corresponds to real events, while some corresponds to myths. However, as in any narrative, the future depends on both.

Fact and fiction must not be mistaken, but it is crucial to understand that both are important in the formation of a national imagery. The fantasies of national identity are usually made up of both fact and fiction. That helps us to understand how the biopics' narratives can articulate historical evidence and national fantasies. Art does not have to be necessarily truthful, but politics does. When Benjamin claimed for the "rendering aesthetic" of politics, he was not defending an abstract idea of "truth," but a subtler understanding of how fact and fiction may intertwine in a work of art. Although less "realistic" than Reaching fot the Moon, Farewell to Europe seems to gesture toward a kind of discontentment that is very contemporary: the rise of authoritarian governments. It is as if a new political energy could emerge from the exhaustion of the Zweigs, heading towards the future. 


\section{References}

Agência Lusa. 2019. "Escritores contestam escolha de Elizabeth Bishop como autora homenageada da FLIP 2020." Observador, 26 November 2019. https:// observador.pt/2019/11/26/escritores-contestam-escolha-de-elizabeth-bishopcomo-autora-homenageada-da-flip-2020/ [accessed June 13, 2021]

Benjamin, Walter. 1969. Illuminations. Translated by Harry Zohn. New York: Schocken Books.

Bishop, Elizabeth. 2014. One Art: Letters. Selected and edited by Robert Giroux. New York: Farrar, Straus and Giroux.

Bishop, Elizabeth, and Robert Lowell. 2010. Words in Air: The Complete Correspondence between Elizabeth Bishop and Robert Lowell. Edited by Thomas Travisano. New York: Farrar, Straus and Giroux.

Dines, Alberto. 2004. Morte no Paraíso: a tragédia de Stefan Zweig. Rio de Janeiro: Rocco.

Folha de São Paulo. 2020. "Curadora da Flip pede demissão e sugere que mulher negra ocupe cargo." Folha de S. Paulo, 12 August 2020. https://www1. folha.uol.com.br/ilustrada/2020/08/flip-anuncia-demissao-de-curadora-quesugere-uma-negra-para-o-cargo.shtml [accessed June 13, 2021]

Freyre, Gilberto. (1933) 2003. Casa Grande \& Senzala: formação da família brasileira sob regime da economia patriarcal. São Paulo: Global.

Gomes, Paulo Emilio Sales. (1973) 2016. "Cinema: trajetória no subdesenvolvimento." In Uma situação colonial? São Paulo: Companhia das Letras.

Holanda, Sérgio Buarque de. (1936) 1995. Raízes do Brasil. São Paulo: Companhia das Letras.

Holanda, Sérgio Buarque de. (1959) 2000. Visão do Paraíso: os motivos edênicos no descobrimento e colonização do Brasil. São Paulo: Publifolha.

Machado, Renato, and Daniel Carvalho. "Em pronunciamento na TV, Bolsonaro diz defender democracia, mas volta a celebrar golpe de 1964." Folha de S. Paulo, 7 September 2020, A6. https://www1.folha.uol.com.br/poder/2020/09/empronunciamento-na-tv-bolsonaro-diz-defender-democracia-mas-celebragolpe-de-1964.shtml [accessed June 13, 2021]

Miskolci, Richard. 2012. O desejo da nação: masculinidade e branquitude no Brasil de fins do XIX. São Paulo: Annablume; Fapesp.

Monteiro, George. org. 2013. Conversas com Elizabeth Bishop. Belo Horizonte: Autêntica.

Oliveira, Carmen L. 1995. Flores raras e banalíssimas: a história de Lota de Macedo Soares e Elizabeth Bishop. Rio de Janeiro: Rocco.

Przybycien, Regina. 2015. Feijão-preto e diamantes: o Brasil na obra de Elizabeth Bishop. Belo Horizonte: Ed. UFMG.

Schwarcz, Lilia, and Heloisa Starling. 2015. Brasil: uma biografia. São Paulo: Companhia das Letras. 
Vidal, Belén. 2013. "Introduction: The Biopic and its Critical Contexts." In The Biopic in Contemporary Film Culture, edited by Tom Brown and Belén Vidal, 1-32. London: Routledge. https://doi.org/10.4324/9780203384572

Zweig, Stefan. (1941) 2013. Brasil: um país do futuro. Translated by Kristina Michahelles. Porto Alegre: L\&PM.

Zweig, Stefan. (1942) 2014. Autobiografia: o mundo de ontem - memórias de um europeu. Translated by Kristina Michahelles. Rio de Janeiro: Jorge Zahar. 